\title{
Optimal salinity and temperature for early developmental stages of Penaeus merguiensis De man
}

\author{
Sherly Zacharia*,1, V.S. Kakati ${ }^{1}$ \\ Central Marine Fisheries Research Institute, P.B. No. 1603, Ernakulam, Cochin-682014, India
}

Received 6 July 2003; received in revised form 10 July 2003; accepted 14 July 2003

\begin{abstract}
The combined effects of temperature and salinity on the hatching success, survival and development of the larval stages of Penaeus merguiensis were investigated in a $4 \times 2$ factorial designed experiment employing two temperatures $\left(29 \pm 1\right.$ and $\left.33 \pm 0.5^{\circ} \mathrm{C}\right)$ and four salinities $(25,30$, 35 and $40 \mathrm{ppt})$. Best percentage of hatch was obtained at $33^{\circ} \mathrm{C}$ and $35 \mathrm{ppt}(87 \%)$ followed by $29{ }^{\circ} \mathrm{C}$ and $35 \mathrm{ppt}(82 \%)$. Similarly during naupliar stages, high survival rate was obtained at $33{ }^{\circ} \mathrm{C}$ and $35 \mathrm{ppt}$ $(89 \%)$. Metamorphosis cycle during the protozoeal stages (protozoea 1 to postlarva 1 ) was extended and survival rate decreased at $25 \mathrm{ppt}$. Development to PL1 was faster at $33{ }^{\circ} \mathrm{C}(7-8$ days $)$ as compared to $29{ }^{\circ} \mathrm{C}(8-10$ days $)$ regardless of the salinity levels. Maximum survival during the protozoeal stages was at $35 \mathrm{ppt}$ followed by $48 \%$ at $33{ }^{\circ} \mathrm{C}$ and $45 \%$ at $29{ }^{\circ} \mathrm{C}$. Results showed that salinity exerted a greater influence than temperature on the survival and development of larvae. Based on the results, the best temperature-salinity combination for larval survival and metamorphosis of $P$. merguiensis is 33 ${ }^{\circ} \mathrm{C}$ and 35 ppt. A salinity range of $30-35$ ppt is ideal for larval development.

(C) 2004 Elsevier B.V. All rights reserved.
\end{abstract}

Keywords: Penaeus merguiensis; Larvae; Salinity; Temperature; Survival; Development

\section{Introduction}

The successful establishment of a species in a given habitat depends on the ability of each of its developing stages to adapt to the existing environment (Charmantier, 1998).

* Corresponding author. Present address: Central Inland Fisheries Research Institute, Barrackpore, Calcutta700120, West Bengal, India. Tel.: +91-33-25921190/91; fax: +91-33-2592-0388.

E-mail addresses: zsherly@yahoo.com (S. Zacharia), vskakati2000@yahoo.co.in (V.S. Kakati).

${ }^{1}$ Tel.: +91-484-2394867, +91-484-2391407. 
Early stages of development are the most sensitive phase in the complex life cycle of marine invertebrates and to maximise their survival larvae should be reared close to optimal conditions. Salinity and temperature are the most important abiotic factors affecting the growth and survival of aquatic organisms (Kinne, 1963, 1964). They are reported to have dramatic effects on the hatching percentage of eggs and also on the survival of the resulting larvae (Preston, 1985). Laboratory and field studies of responses of eggs and larvae of marine organisms to the combined effects of temperature and salinity would lead to a greater understanding of the significance of these factors on survival during early larval development. Thus, defining these optimal conditions for culture of euryhaline marine species may be the fundamental for developing rearing protocol for these species.

Studies about the salinity and temperature optima for penaeid larvae have been limited to only a few species (Preston, 1985; Kumulu and Jones, 1993; Parado-Estepa et al., 1993; Kumulu et al., 2000). The optimal environmental conditions for growth are speciesspecific and differ between life-history stage and season (Costlow et al., 1960; Bas and Spivak, 2000). During the nauplius stage, the rate of development is mainly influenced by abiotic factors, as the larvae do not feed at this stage. On reaching the protozoeal stage feeding commences and the rate of development is influenced by the abundance of suitable food in addition to salinity and temperature. Salinity tolerances become broader as larval development proceeds. Protozoeal stages had the lowest tolerance to changes in salinity, while mysis stages were the least affected in Penaeus marginatus (Gopalakrishnan, 1976) and Metapenaeus bennettae (Preston, 1985). Conventionally, larval cultures of penaeid shrimp are been done in full strength seawater (Chen, 1990; Parado-Estepa, 1998; Kumulu et al., 2000) though temperatures ranging from 24 to $32{ }^{\circ} \mathrm{C}$ and salinities ranging from 27 to $34 \mathrm{ppt}$ have been found suitable for development of penaeid larvae (Hudinaga, 1942; Cook and Murphy, 1969). It is thus evident that proper attention should be paid to these physical properties of seawater used for rearing the larvae for large-scale aquaculture practices.

Penaeus merguiensis popularly known as banana shrimp occurs through out the Asian and Australian tropical and subtropical waters. It represents an important regional fishing activity in Karwar, North Karnataka, India and assumes importance mainly due to its large size and export value. The studies on the optimum conditions during the early stages of development will help to determine the adequate conditions for optimal production and culture of this species. Hence, the present study was conducted to examine variation in survival and development of early larval stages of $P$. merguiensis in response to the combined effects of temperature and salinity under laboratory conditions.

\section{Materials and methods}

\subsection{Experimental shrimp}

Wild mature $P$. merguiensis females (35-50 g) with implanted spermatophores were obtained from commercial gill nets off Karwar coast, India. The shrimps were transported to the laboratory in polythene bags under oxygenated conditions and were maintained 
individually in 100-1 tanks containing seawater of 32-33 ppt salinity and temperature of $29 \pm 1{ }^{\circ} \mathrm{C}$. Spawning took place during night and viable eggs (ca. 154,000 eggs/female) hatched within $24-26 \mathrm{~h}$. Nauplii were concentrated to a point by attracting them to a light source at the surface based on the phototactic response (Browdy, 1998) and transferred to 20-1 container. Exogenous food was supplied as soon as the larvae reached the last (sixth) naupliar stages and consisted of a mixture of Chaetoceros calcitrans (50 cells $/ \mu \mathrm{l}$ ) and Isochrysis galbana (30 cells/ $\mu \mathrm{l})$ through out the culture period. Algal concentration was monitored daily using a haemocytometer. Freshly hatched nauplii of Artemia species (10 nauplii $/ \mathrm{ml}$ ) were added to the culture tanks when $50 \%$ of the larvae entered into the mysis (M1) stage.

\subsection{Experimental design}

The combined effect of salinity and temperature on hatching rate, survival and rate of metamorphosis was determined in the laboratory using a balanced $4 \times 2$ factorial designed experiment with two temperatures viz., room temperature $\left(29 \pm 1{ }^{\circ} \mathrm{C}\right)$ and elevated temperature $\left(33 \pm 0.5^{\circ} \mathrm{C}\right)$ and four salinities $(25,30,35$ and $40 \mathrm{ppt})$. Vertical glass troughs of 2-1 capacity were used for the experiment. Temperature was maintained within $\pm 0.5^{\circ} \mathrm{C}$ using thermostatically controlled water baths. The required salinity was obtained either by diluting seawater with freshwater or by mixing filtered seawater with sea salt (Tata, India) to keep variation within $\pm 1 \mathrm{ppt}$. The experiment followed a completely randomised design, using the larvae from a single spawn to minimise variability between experimental units (Gallardo et al., 1995). Each combination of temperature-salinity was conducted in two replicates. The beakers were kept mixed and saturated with oxygen using one air stone per container and maintained at normal day-night illumination. Salinity and temperature were measured each morning using a portable refractometer (ERMA, Japan) and a mercury thermometer, respectively. All cultures were covered to prevent evaporation.

\subsection{Larval development and survival}

Stages of development (egg, nauplii and protozoea) were treated separately and larvae were reared to the stage required for each experiment in 20-1 glass beakers. Stocking densities in the experimental vessels were 100 eggs/l, 100 nauplii/l and 50 protozoea/l. In order to avoid abrupt changes in temperature and salinity, larvae were initially placed in $500 \mathrm{ml}$ of water at ambient conditions and allowed to acclimatise to the desired experimental temperature and salinity levels over a period of $2 \mathrm{~h}$. The larvae in each flask were counted and random samples of 10-15 larvae were staged (Motoh and Buri, 1979) everyday throughout the culture period. Size was not used to evaluate the effect of salinity and temperature. Some healthy larvae were found to lie on the bottom of the cultured vessel among the dead and moribund individuals. Larvae were considered dead when limb movement had ceased when nudged by a needle. Each experiment was continued until larvae at the lowest temperature had either reached the relevant stage or were dead. Time required for $50 \%$ of the larvae in a given treatment to moult to the next successive developmental stages and relative survivals of the larvae was used to infer the suitability of temperature-salinity range. 


\subsubsection{Hatching}

Once eggs were observed in the water column, they were removed by siphoning and collected using sieve $(100 \mu \mathrm{m})$ and transferred to experimental units maintained at different temperature-salinity combinations. Hatching success of eggs was determined after $24 \mathrm{~h}$. Twenty 1-ml samples were collected from each experimental unit using a pipette and the hatching success was recorded as total nauplii/total eggs $\times 100$.

\subsubsection{Naupliar stage}

Within $1 \mathrm{~h}$ after hatching, nauplii were collected from the hatching tanks, acclimatised and transferred to the experimental units. Survival was recorded after a period of $24 \mathrm{~h}$. No food was supplied during the tests with nauplii. The trial was terminated after larvae reached protozoea 1 .

\subsubsection{Protozoeal stages}

Protozoea 1 (PZ1) acclimatised to the required salinity and temperature levels were stocked into experimental units with algal culture and mean stage index (MSI) was calculated daily using the formula:

$$
\mathrm{MSI}=\sum\left(S \times P_{\mathrm{s}}\right)
$$

where $S$ represents the larval stage and $P_{\mathrm{s}}$ represents the proportion of larvae still alive at stage $S$ (Lovett and Felder, 1988; Parado-Estepa, 1998). Absolute values of 1 to 7 were assigned consecutively to the larval stages (protozoea 1 to postlarvae 1).

The combined effects of both temperature and salinity on larval survival were investigated from protozoea (PZ1) to postlarvae (PL1) stages. Time required for $50 \%$ of protozoea to metamorphose to postlarvae was estimated.

\subsection{Statistical analyses}

Data were analysed with two-way ANOVA ( $F$ test, $P<0.05$ ) to assess the effect of salinity, temperature and their interaction on hatching percentage and survival of naupliar and protozoeal stages. The percentages of survival values were arcsine transformed to make the variance independent of the mean (Leung-Trujillo and Lawrence, 1987). If significant difference were indicated at the 0.05 level, then Scheffé's test was used to compare treatments (Scheffé, 1943). Figures present untransformed data on mean percentage \pm standard deviation. The equality of regression lines of rate of change of MSI over days was also tested.

\section{Results}

\subsection{Hatching}

The hatching success of $P$. merguiensis eggs followed a general trend of being lowest at the lowest salinity and temperature level (Fig. 1). The percentages of hatch at different 


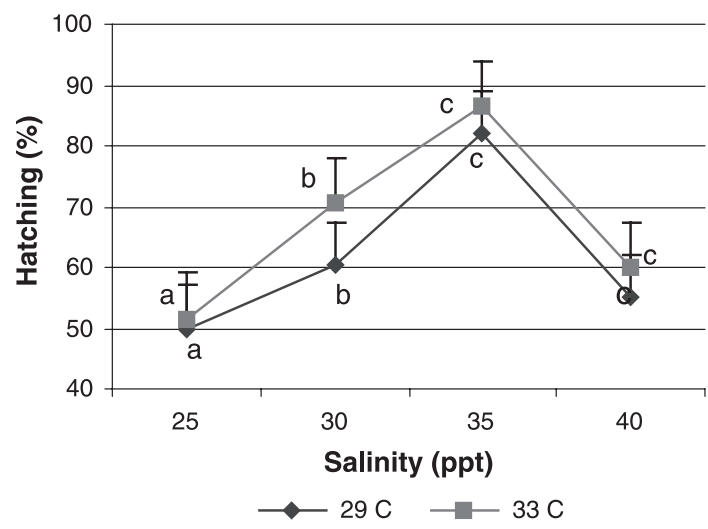

Fig. 1. Hatching percentage of $P$. merguiensis at various salinities and temperatures. Symbols represent means and bars represent S.E. of the means. Means with a common letter are not significantly different from each other (ANOVA, $P<0.05)$.

salinities tested were in general higher at $33{ }^{\circ} \mathrm{C}$ than at $29{ }^{\circ} \mathrm{C}$. The highest mean hatch rate was at $33{ }^{\circ} \mathrm{C}$ and $35 \mathrm{ppt}(86.5 \%)$ followed by $29{ }^{\circ} \mathrm{C}$ and $35 \mathrm{ppt}(82 \%)$.

The hatching percentage of eggs at different temperature-salinity combinations was principally determined by salinity. The effect of temperature was less pronounced and there was no significant interaction between salinity and temperature on the rate of embryonic development at a $5 \%$ level $(P=0.05)$.

\subsection{Survival of naupliar stages}

Metamorphosis from the first naupliar stage through the first protozoeal stage (PZ1) was successful in all salinities at both tested temperatures, but with varying degree of survival percentages. Survival rates of more than $50 \%$ were obtained at 30, 35 and $40 \mathrm{ppt}$ in both the tested temperatures. In general, irrespective of the salinities, percentages of survival were greater at $33{ }^{\circ} \mathrm{C}$ than that at $29{ }^{\circ} \mathrm{C}$ (Fig. 2). The highest survival percentage was obtained at $33{ }^{\circ} \mathrm{C}$ and $35 \mathrm{ppt}(89 \%)$ followed by $29{ }^{\circ} \mathrm{C}$ and $35 \mathrm{ppt}(78.5 \%)$. The animals kept at $25 \mathrm{ppt}$ were lethargic and had the lowest survival during the experimental period. From the results obtained, it was evident that the optimum temperature and salinity conditions at hatching $\left(33{ }^{\circ} \mathrm{C}\right.$ and $\left.35 \mathrm{ppt}\right)$ also favoured naupliar metamorphism and survival.

Statistical analyses of the data by means of two-way ANOVA showed that, of the two factors studied, the effect of salinity on larval survival from nauplius to protozoea I was highly significant $(P<0.01)$. Though temperature had a significant effect on naupliar survival $(P<0.05)$, temperature-salinity interaction had no effect on the same.

\subsection{Protozoea to postlarval stage}

The larvae metamorphosed to the next successive stage in all the salinities tested, but the time taken to reach postlarvae was significantly greater at $29{ }^{\circ} \mathrm{C}(8-10$ days $)$ than at 


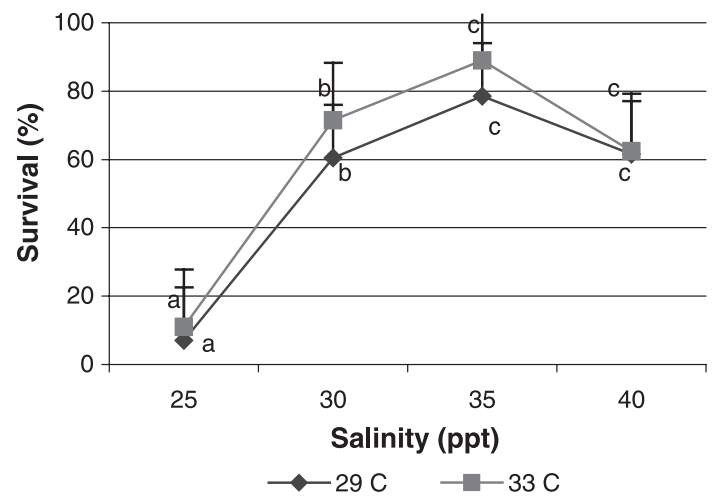

Fig. 2. Survival of naupliar stages of $P$. merguiensis at various salinities and temperatures. Symbols represent means and bars represent S.E. of the means. Means with a common letter are not significantly different from each other (ANOVA, $P<0.05$ ).

$33{ }^{\circ} \mathrm{C}(7-8$ days). The observation was continued till the larvae maintained at the lowest salinity metamorphosed to postlarvae and the time taken generally increased with decrease in salinity. The fastest larval development until M1 took place at 35 and 40 ppt at both test temperatures. At all these temperature-salinity combinations, it took 4 days for the PZ1 larvae to develop to M1 stage. Similarly, fastest development to PL was also at 35 and 40 ppt at both tested temperatures where the larvae took 7 days to reach PL. The slowest larval development occurred at $29{ }^{\circ} \mathrm{C}$ and $25 \mathrm{ppt}$ (10 days).

The survival rates at different salinities were more or less same at both tested temperatures (Table 1). At $33{ }^{\circ} \mathrm{C}$ and $35 \mathrm{ppt}, 52 \%$ of the larvae metamorphosed to M1 stage while at $29{ }^{\circ} \mathrm{C}$ and $35 \mathrm{ppt}, 49 \%$ reached this stage. At the termination of the experiment, the best survival from PZ1-PL1 was registered at $33{ }^{\circ} \mathrm{C}$ and 35 ppt with an average of $48 \%$ followed by $29{ }^{\circ} \mathrm{C}$ and $35 \mathrm{ppt}(45 \%)$. In contrast, at the lowest salinity level (25 ppt), only $13 \%$ of the larvae metamorphosed to PL stage at $29{ }^{\circ} \mathrm{C}$ and $15 \%$ at 33 ${ }^{\circ} \mathrm{C}$. Statistical analyses of the survival data by means of two-way ANOVA showed that salinity exerted a significantly higher influence on the survival at different stages of

Table 1

Survival and duration of development of $P$. merguiensis larvae grown at different salinity and temperature combinations from PZ1 stage to PL1 stage

\begin{tabular}{|c|c|c|c|c|c|}
\hline \multirow[t]{2}{*}{ Temperature } & \multirow[t]{2}{*}{ Salinity (ppt) } & \multicolumn{2}{|c|}{ Survival (\%) } & \multicolumn{2}{|c|}{ Duration (days) } \\
\hline & & M1 & PL1 & M1 & PL1 \\
\hline \multirow[t]{4}{*}{$29^{\circ} \mathrm{C}$} & 25 & $17 \pm 2.12^{\mathrm{a}}$ & $13 \pm 3.54^{\mathrm{a}}$ & 5 & 10 \\
\hline & 30 & $44 \pm 4.24^{\mathrm{b}}$ & $33 \pm 1.41^{\mathrm{b}}$ & 5 & 9 \\
\hline & 35 & $49 \pm 8.54^{\mathrm{c}}$ & $45 \pm 7.07^{\mathrm{c}}$ & 4 & 7 \\
\hline & 40 & $45 \pm 5.66^{\mathrm{c}}$ & $40 \pm 5.66^{\mathrm{c}}$ & 4 & 7 \\
\hline \multirow[t]{4}{*}{$33^{\circ} \mathrm{C}$} & 25 & $18 \pm 5.66^{\mathrm{a}}$ & $15 \pm 2.12^{\mathrm{a}}$ & $4.5-5$ & 8 \\
\hline & 30 & $42 \pm 1.41^{b}$ & $37 \pm 1.41^{\mathrm{b}}$ & $4.5-5$ & $7.5-8$ \\
\hline & 35 & $52 \pm 4.24^{\mathrm{c}}$ & $48 \pm 5.65^{\mathrm{c}}$ & 4 & 7 \\
\hline & 40 & $46 \pm 2.83^{c}$ & $42 \pm 2.83^{c}$ & 4 & 7 \\
\hline
\end{tabular}

Values in the same column marked with different superscripts are significantly different $(P<0.05)$. 
metamorphosis from PZ1-PL1 stages $(P<0.05)$. The effect of temperature and temperature-salinity interaction was not significant at $5 \%$ level.

\subsection{MSI}

MSI was determined daily. No mortality was observed during counting and transfer of larvae. On the eighth day, the experiment conducted at $33{ }^{\circ} \mathrm{C}$ was terminated and the highest MSI value was observed at $35 \mathrm{ppt}$ followed by $40 \mathrm{ppt}$. On termination of the experiments maintained at $29{ }^{\circ} \mathrm{C}$ on the tenth day, MSI values were more or less the same at 35 and 40 ppt. Comparison of the progression of MSI over days at different salinity levels at both 29 and $33{ }^{\circ} \mathrm{C}$ is shown in Fig. 3. At 25 and $30 \mathrm{ppt}$, the increase in MSI over days was higher at $29{ }^{\circ} \mathrm{C}$ compared to $33{ }^{\circ} \mathrm{C}$ for a period of 4 days after which a higher rate of MSI change over days was obtained at $33{ }^{\circ} \mathrm{C}$. At $35 \mathrm{ppt}$, the rate of change of MSI was higher at $33{ }^{\circ} \mathrm{C}$ throughout the experiment while at $40 \mathrm{ppt}$, the change in MSI over days was more or less the same at both the tested temperatures for a period of 3 days, followed by a higher rate at $33{ }^{\circ} \mathrm{C}$ till the termination of the experiment. Testing the equality of regression lines showed that rate of change of MSI over days at 25 and $40 \mathrm{ppt}$

MSI values at $25 \mathrm{ppt}$

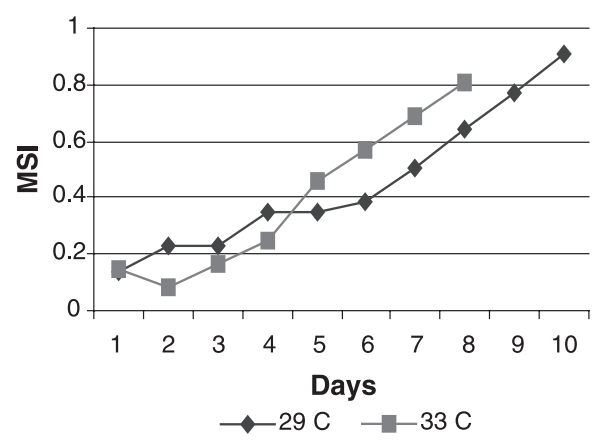

MSI values at $35 \mathrm{ppt}$

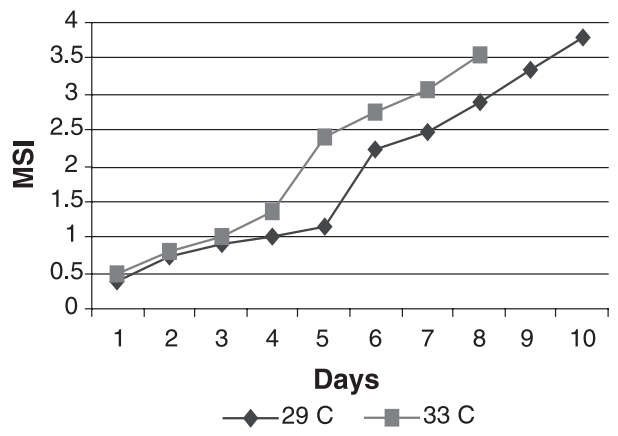

MSI values at $30 \mathrm{ppt}$

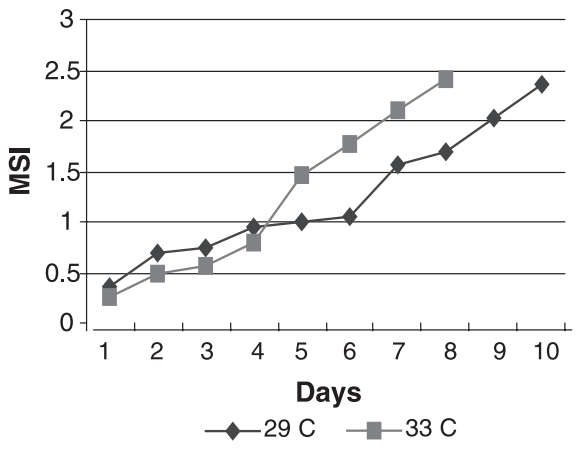

MSI values at $40 \mathrm{ppt}$

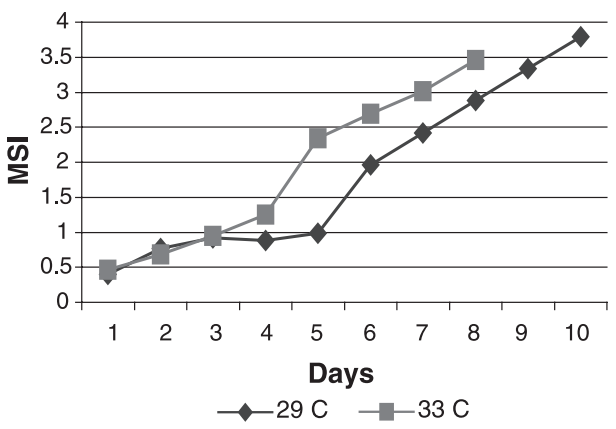

Fig. 3. Comparison of the progression of mean stage index (MSI) over days during protozoeal stages of P. merguiensis at different salinity and temperature levels. 
was statistically insignificant while at 30 and $35 \mathrm{ppt}$, the difference was significant at 5\% level. Based on larval survival and progression of MSI, a salinity range of 30-35 ppt appears ideal for the larval development of P. merguiensis.

\section{Discussion}

The completion of the life cycle of $P$. merguiensis in captivity was related to the ability of the species to tolerate variations in salinity and temperature. The pattern of larval development of $P$. merguiensis followed closely that of other species of the genus. Roberts (1971) reported each species to have a unique range of salinities suitable for embryonic development and hatching, which bears no a priori relationship to the tolerance of adults or larvae. Dissimilarities in the response of larvae of P. merguiensis were observed at both the tested temperatures. Hatching success and survival of naupliar stages were maximum at 33 ${ }^{\circ} \mathrm{C}$ and $35 \mathrm{ppt}$ followed by $29^{\circ} \mathrm{C}$ and $35 \mathrm{ppt}$. Other tested salinities retarded hatching success and naupliar survival, though the potency of the effect was different at the two tested temperatures. The results are in agreement with that reported by Nisa and Ahmed (2000) where a salinity of $35 \mathrm{ppt}$ was reported as optimal for hatching success and naupliar survival of $P$. merguiensis. In contrast, highest mean hatching rates in $P$. monodon were obtained at the temperature-salinity combination of $23{ }^{\circ} \mathrm{C}$ and $33 \mathrm{ppt}$ while survival rate of nauplius to first protozoeal stage was highest at $28{ }^{\circ} \mathrm{C}$ and $33 \mathrm{ppt}$ followed by $33{ }^{\circ} \mathrm{C}$ and $33 \mathrm{ppt}$ and 23 ${ }^{\circ} \mathrm{C}$ and 33 ppt (Reyes, 1985). Studies conducted on penaeid species like P. kerathurus (Klaoudatos, 1978), P. plebejus and Metapenaeus macleayi (Preston, 1985), M. ensis (Chu and So, 1987), P. penicillatus, M. affinis and Parapenaeopsis stylifera (Nisa and Ahmed, 2000) and P. monodon (Parado-Estepa et al., 1993) showed that the best temperature and salinity range for hatching and naupliar survival is between $27-29{ }^{\circ} \mathrm{C}$ and $30-35 \mathrm{ppt}$.

In each species, tolerance to different temperatures and salinities was least during the development of the protozoea stages and greatest during the development of mysis stages (Gopalakrishnan, 1976; Preston, 1985). Earlier studies on rearing larvae of penaeid shrimp under laboratory conditions revealed similar results of high mortality rate during protozoeal stage, particularly at the first and third stages in Penaeus japonicus (Hudinaga, 1942), P. marginatus (Gopalakrishnan, 1976) and M. bennettae (Preston, 1985). Similarly in the present study, mortality was high during the development of protozoea stages than at any other stage of development. Salinity tolerances became broader as larval development proceeds. In comparison with protozoea stage, there was a marked change in the response of mysis stage to the combined effect of temperature and salinity with an increased tolerance to differences in temperature and salinity as revealed by the high MSI values. Similar results of marked increase in salinity tolerance on reaching mysis stage have been reported for many penaeid shrimp which spawn offshore like $P$. marginatus (Gopalakrishnan, 1976), P. merguiensis (Prasad et al., 1988; Nisa and Ahmed, 2000), P. plebejus and M. macleayi (Preston, 1985). The relative difference of the mysis stages to a range of salinities at both tested temperatures suggested a fundamental change in the mechanisms determining the limits of tolerance of larvae.

The results show that salinity had a greater influence on survival than temperature during larval development. Among the eight combinations of salinity-temperature 
conditions levels, the highest larval survival was obtained at $33{ }^{\circ} \mathrm{C}$ and $35 \mathrm{ppt}(48 \%)$ followed by $29{ }^{\circ} \mathrm{C}$ and $35 \mathrm{ppt}$ (45\%). Survival was considerably low at $25 \mathrm{ppt}$ at both tested temperatures. Although temperature did not seem to affect survival for the present study, it is known to influence Penaeid growth and therefore the length of time that shrimp spend in each larval stage. Parado-Estepa (1998) showed high temperature $\left(30-34{ }^{\circ} \mathrm{C}\right)$ to significantly increase the growth and metamorphosis rate during the protozoeal stages and mysis stages as compared to $22{ }^{\circ} \mathrm{C}$. Similarly, in P. merguiensis, metamorphosis cycle was extended and survival rate decreased at $25 \mathrm{ppt}$ and ecdysis cycle was shortened at $33{ }^{\circ} \mathrm{C}$. High temperature $\left(33^{\circ} \mathrm{C}\right)$ significantly increased metamorphosis rate during both protozoea and mysis stages. Development to PL1 was faster at $33{ }^{\circ} \mathrm{C}$ ( $7-8$ days) as compared to $29{ }^{\circ} \mathrm{C}$ (8-10 days) regardless of the salinity levels confirming the suggestion that high temperature to a certain point increases the moulting frequency and larval growth of penaeid shrimp (Staples and Heales, 1991; O’Brien, 1994; Parado-Estepa, 1998).

Based on the results, the best temperature-salinity combination for larval survival and metamorphosis of $P$. merguiensis was $33{ }^{\circ} \mathrm{C}$ and $35 \mathrm{ppt}$ while a salinity range of 30-35 ppt appears ideal for larval development. This environmental range is based on the results considering survival as the most important indices and MSI as a factor to define the optimum level with greater precision (Tobias-Quinitio and Villegas, 1982; Alfonso et al., 1988). The present study thus confirms that at least through its early larval stages, $P$. merguiensis needs oceanic salinities for survival.

\section{Acknowledgements}

We are thankful to Director, CMFRI, Cochin, for providing facilities. One of the authors (Sherly Zacharia) wishes to express thanks to the Indian Council of Agricultural Research, New Delhi, for the award of fellowship.

\section{References}

Alfonso, E., Martínez, L., Gelabert, R., Leal, S., 1988. Alimentación de larvas del camarón Penaeus schmitti 1. Diatomeas y flagelados. Rev. Investig. Mar. 9 (1), 47-58.

Bas, C.C., Spivak, E.D., 2000. Effect of salinity on embryos of two southwestern Atlantic estuarine grapsid crab species cultured in vitro. J. Crustac. Biol. 20 (4), 647-656.

Browdy, C., 1998. Recent developments in penaeid broodstock and seed production technologies: improving the outlook for superior captive stocks. Aquaculture 164 (1-4), 3-21.

Charmantier, G., 1998. Ontogeny of osmoregulation in crustaceans: a review. Invertebr. Reprod. Dev. 33 (2-3), $177-190$

Chen, L.C., 1990. Aquaculture in Taiwan Blackwell, Oxford, England. 273 pp.

Chu, K.H., So, B.S.H., 1987. Changes in salinity tolerance during larval development of the shrimp Metapeneaus ensis (De Haan). Asian Mar. Biol. 4, 41-48.

Cook, H.L., Murphy, M.A., 1969. The culture of larval penaeid shrimp. Trans. Am. Fish. Soc. 98, $751-754$.

Costlow Jr., J.D., Bookhout, C.G., Monroe, R., 1960. The effect of salinity and temperature on larval development of Sesarma cinereum (Bosc.) reared in the laboratory. Biol. Bull. 118, 183-202.

Gallardo, P.P., Alfonso, E., Gaxiola, G., Soto, L.A., Rosas, C., 1995. Feeding schedule for Penaeus setiferus larvae based on diatoms (Chaetoceros ceratosporum), flagellates (Tetraselmis chuii) and Artemia nauplii. Aquaculture 131, 239-252. 
Gopalakrishnan, K., 1976. Larval rearing of red shrimp Penaeus marginatus (Crustacea). Aquaculture 9, 145 - 154.

Hudinaga, M., 1942. Reproduction, development and rearing of Penaeus japonicus Bate. Jpn. J. Zool. 10 (2), $305-393$.

Kinne, O., 1963. The effects of temperature and salinity on marine and brackish water animals: I. Temperature. Oceanogr. Mar. Biol. Ann. Rev. 1, 301-340.

Kinne, O., 1964. The effects of temperature and salinity on marine and brackish water animals: II. Salinity and temperature-salinity combinations. Oceanogr. Mar. Biol. Ann. Rev. 2, 281-339.

Klaoudatos, S., 1978. Breeding of Penaeus kerathurus in the laboratory as a proposition to culture them on a commercial scale. Thalassographica 2 (1), 99-113.

Kumulu, M., Jones, D.A., 1993. Optimum rearing conditions for rearing Penaeus indicus larvae. Spec. Publ.-Eur. Aquac. Soc. 19. 142 pp.

Kumulu, M., Eroldogan, O.T., Aktas, M., 2000. Effects of temperature and salinity on larval growth, survival and development of Penaeus semisulcatus. Aquaculture 188, 167-173.

Leung-Trujillo, J.R., Lawrence, A.L., 1987. Observations on the decline in sperm quality of Penaeus setiferus under laboratory conditions. Aquaculture 65, 363-370.

Lovett, D.L., Felder, D.L., 1988. Evaluation of the rotifer Brachionus plicatilis as a substitute for Artemia in feeding larvae of Macrobrachium rosenbergii. Aquaculture 71, 331-338.

Motoh, H., Buri, P., 1979. Larvae of decapod crustacea of the Philippines: IV. Larval development of the banana prawn, Penaeus merguiensis reared in the laboratory. Bull. Jpn. Soc. Sci. Fish. 45, 1217-1235.

Nisa, Z., Ahmed, M., 2000. Hatching and larval survival of important penaeid shrimps of Pakistan in different salinities. Pak. J. Zool. 32 (2), 139-143.

O'Brien, C.J., 1994. The effects of temperature and salinity on growth and survival of juvenile tiger prawn Penaeus esculentus. J. Exp. Mar. Biol. Ecol. 183 (1), 133-145.

Parado-Estepa, F.D., 1998. Survival of Penaeus monodon postlarvae and juveniles at different salinity and temperature levels. Isr. J. Aquac.-Bamidgeh 50 (4), 174-183.

Parado-Estepa, F.D., Llobrera, J.A., Villaluz, A., Salde, R., 1993. Survival and metamorphosis of Penaeus monodon larvae at different salinity levels. Isr. J. Aquac.-Bamidgeh 45 (1), 3-7.

Prasad, C.V.N., Prasad, P.N., Neelakantan, B., 1988. Salinity tolerance in the larvae (Mysis III) of banana prawn Penaeus merguiensis (De Man). Seaf. Export J. 20 (9), 21-26.

Preston, N., 1985. The effects of temperature and salinity on survival and growth of larval Penaeus plebejus, Metapenaeus macleyi and M. bennettae. In: Rothlisberg, P.C., Hill, B.J., Staples, D.J. (Eds.), Second Australian National Prawn Seminar. NPS2, Cleveland, Australia, pp. 31-40.

Reyes, E.P., 1985. Effect of temperature and salinity on the hatching of eggs and larval development of sugpo Penaeus monodon. Proceedings of the First International Conference on the Culture of Penaeid Prawns/ Shrimps, Iloilo City, Philippines, Aquaculture Department, Southeast Asian Fisheries Development Centre, Iloilo, Philippines, Dec. 4-7, 1984, pp. 177-178.

Roberts, M., 1971. Larval development of Pagurus longicarpus (Say) reared in the laboratory: II. Effects of reduced salinity on larval development. Biol. Bull. 140, 104-116.

Scheffé, H., 1943. On solutions of the BEHRENS-FISHER problem based on the $t$-distribution. Ann. Math. Stat. $14,35-44$.

Staples, D.J., Heales, D.S., 1991. Temperature and salinity optima for growth and survival of juvenile banana prawn Penaeus merguiensis. J. Exp. Mar. Biol. Ecol. 154, 251-274.

Tobias-Quinitio, E., Villegas, C.T., 1982. Growth, survival and macronutrient composition of Penaeus monodon Fabricius larvae fed with Chaetoceros calcitrans and Tetraselmis chuii. Aquaculture 29, 253-260. 